\title{
Magnetic logs from the Lopra-1/1 A and Vestmanna-1 wells, Faroe Islands
}

\author{
Niels Abrahamsen and Regin Waagstein
}

Susceptibility measurements from cores (representing basalt, lapilli-tuffs and tuffs) and magnetic logs from the Lopra-1/1A well are presented. The basalts fall into high- and low-susceptibility groups with no overlap. The high-susceptibility basalts (seven cores) have susceptibilities between 4 and $88 \times 10^{-3}$ SI and consist of basalt with $<1 \%$ vesicles from thick massive units. The low-susceptibility basalts are intergranular, intersertal or hypocrystalline and contain no or very little $(<1 \%)$ visible magnetite, are generally more altered than the high-susceptibility basalts and have susceptibilities in the range from 0.6 to $1.4 \times 10^{-3} \mathrm{SI}$ (seven cores). The susceptibility of ten volcaniclastites of lapilli-tuff or tuff varies from 0.4 to $3.8 \times 10^{-3}$ SI. The cores from the Lopra-1/1A well reveal a bimodal distribution of magnetic susceptibility. Low susceptibilities ranging from 0.4 to 4 are characteristic of altered basalts poor in magnetite, lapilli-tuffs and tuffs. Thus single measurements of susceptibility are of little use in discriminating between these three types of rock.

Susceptibility logs from the Lopra-1/1A well show that the variation below $3315 \mathrm{~m}$ distinguishes clearly between volcaniclastics (hyaloclastites) with low and fairly constant susceptibility and basalt beds of between 5 and $10 \mathrm{~m}$ thickness (with high susceptibility). The volcaniclastics comprise some $60-70 \%$ of the sequence between 3315 and $3515 \mathrm{~m}$ with the maximum continuous sediment layer being $80 \mathrm{~m}$ thick. A $11 / 2 \mathrm{~m}$ core of solid basalt at $2381 \mathrm{~m}$ and sidewall cores of basalt from the Lopra$1 / 1 \mathrm{~A}$ well have a mean susceptibility of $22.1 \pm 3.5 \times 10^{-3} \mathrm{SI}$ (standard deviation $(\sigma)=23.6$, number of samples $(\mathrm{N})=46$ ), while samples of hyaloclastite (lapilli-tuff and tuff) have a mean susceptibility of $0.85 \times 10^{-3} \mathrm{SI}(\sigma=0.39, \mathrm{~N}=17)$.

The mean values of the rock magnetic parameters for 303 basalt plugs from the Vestmanna- 1 well are: $\mathrm{Q}_{\text {ave }}=13.3 \pm 0.6(\sigma=11), S_{\text {ave }}=11.8 \pm 0.6 \times 10^{-3} \mathrm{SI}(\sigma=11)$ and $J_{\text {ave }}=4.64 \pm 0.25 \mathrm{~A} / \mathrm{m}(\sigma=4.4)$. The reversely polarised, lowermost (hidden) part of the $c .41 / 2 \mathrm{~km}$ thick lower basalt formation correlates with Chron C26r. The upper (exposed) part of the lower basalt formation correlates with Chrons C26n, C25r and C25n and the more than $2.3 \mathrm{~km}$ thick middle and upper basalt formations correlate with Chron C24n.3r.

Keywords: Magnetic logging, rock magnetism, susceptibility, NRM, magnetic reversals, Faroe Islands, Lopra, Vestmanna, North Atlantic

N.A., Department of Earth Sciences, University of Aarhus, Finlandsgade 8, DK-8200 Aarhus N, Denmark.

E-mail: Abraham@geo.au.dk

R.W., Geological Survey of Denmark and Greenland, Øster Voldgade 10, DK-1350 Copenhagen K, Denmark. 


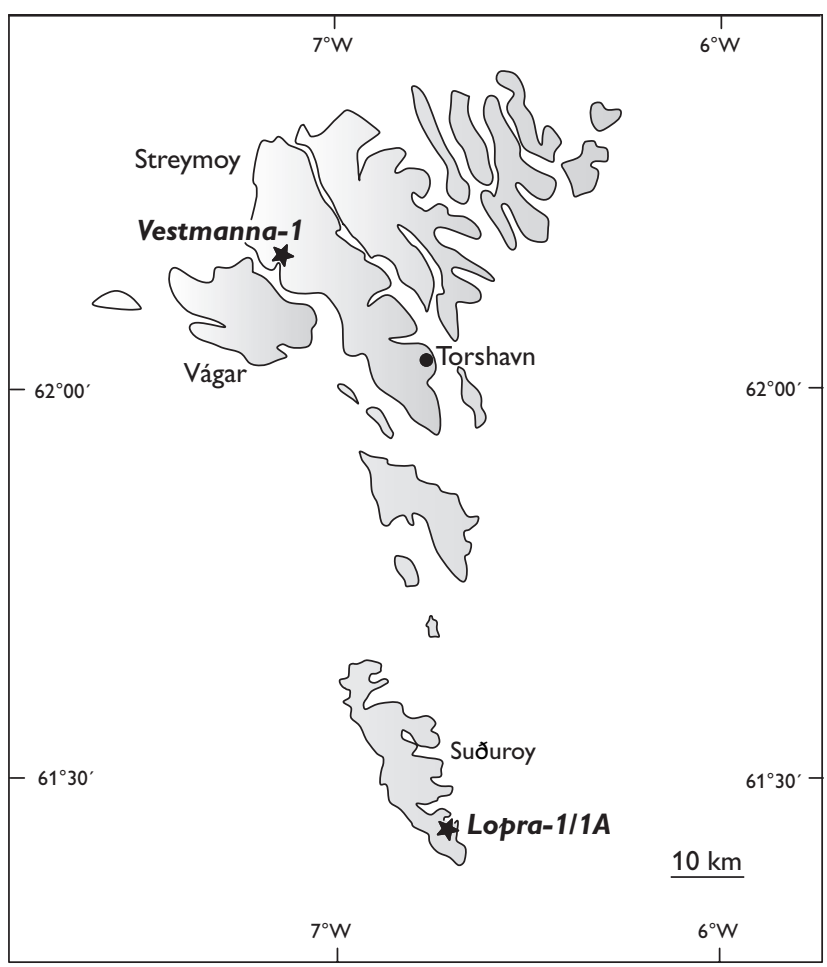

Fig. 1. Index map of the Faroe Islands with the positions of the Lopra-1/1A and Vestmanna-1 wells indicated with stars.

Information on rock magnetic properties, susceptibility and natural remanent magnetisation (NRM) may be useful for detecting changes in rock type, structure and magnetic mineral content of rocks penetrated by boreholes. Magnetic polarity is also a tool potentially of use in dating. Although magnetic surveying has a long history in prospecting and mining geophysics (e.g. Parasnis 1979), magnetic logging (using susceptibility) in boreholes was first developed in the 1950s with new electronic types of equipment (e.g. Broding et al.1952; Levanto 1958; Barthés et al. 1999).

Logging with the purpose of magnetic polarity determinations began even later (e.g. Pozzi et al.1988, 1993; Bouisset \& Augustin 1993; Ito \& Nogi 1995). Magnetic logging instruments were developed for down-hole mapping of the magnetic field as a correlation- and datingtool using magnetostratigraphy. Reversals recorded in a borehole may be used for dating if they can be correlated with the geomagnetic polarity time scale (GPTS). The GPTS was firmly established in the early 1960s by radiometric dating of reversals recorded in young volcanic sequences on land (e.g. Cox et al.1963) and by relating the polarity reversals from land to marine magnetic anomalies observed over the oceans (Vine \& Matthews 1963). This revived the idea of continental drift and supported the new paradigm of plate tectonics. In the following years the polarity scale was extended linearly backwards through Mesozoic time by correlation of long sequences of marine anomalies with the shorter land-based records (Heirtzler et al.1968).

The present paper deals with the results of magnetic logging of the Lopra-1/1A well, situated on Suðuroy, the southernmost of the Faroe Islands (Fig. 1). The magnetic logs were acquired by Schlumberger Ltd. in 1997 as part of an extensive logging programme run in connection with deepening of the well. The logs cover a major part of the Faroes lower basalt formation (Waagstein 1988, Waagstein et al. 2001). The log-like results of rock magnetic properties obtained from the continuously cored Vestmanna-1 well through a younger part of the Faroes basalt succession (Abrahamsen et al. 1984) are summarised for comparison.

\section{Magnetic logging in Lopra-1/1A}

A geological high-resolution magnetometer tool (GHMT) was run by Slumberger Ltd. from 3101 to $2168 \mathrm{~m}$ in the deepened part of the Lopra- 1 well and subsequently from 3519 to $2998 \mathrm{~m}$ in the sidetracked Lopra-1A. The kickoff depth of the sidetrack is $3091 \mathrm{~m}$, which means that the two log sections overlap from 3091 to $2998 \mathrm{~m}$. The two logs have been combined into a single log using an arbitrary splicing point at $3000 \mathrm{~m}$.

The GHMT tool records two types of magnetic measurements; the magnetic susceptibility (RMAGS) and the total magnetic induction (MAGB). Examples of the records obtained are shown for the whole sequence in Figs 2-5. A shorter section is shown in more detail in Fig. 6.

The main objective of the deepening of the Lopra-1 well was to drill through the basalt formations to the expected underlying sediments. The dipole-dipole sensor susceptibility measurement tool (SUMT) was therefore set to the low-resolution mode. The nuclear magnetic resonance magnetometer (NRMT) was designed to measure the total magnetic induction in the borehole within a working range of only $5000 \mathrm{nT}$ around a preset expected value (Schlumberger Ltd., personal communication 1997) which was unfortunately much less than the actual ranges of 30000 and $70000 \mathrm{nT}$ present within the hole. Another purpose of the short working ranges applied was to protect the tool electronics, which were designed for weakly magnetic sediments rather than strongly magnetic volcanic rocks.

The settings for the magnetic tools were not optimal for the basalt-dominated section actually drilled, as the 
Lopra-1

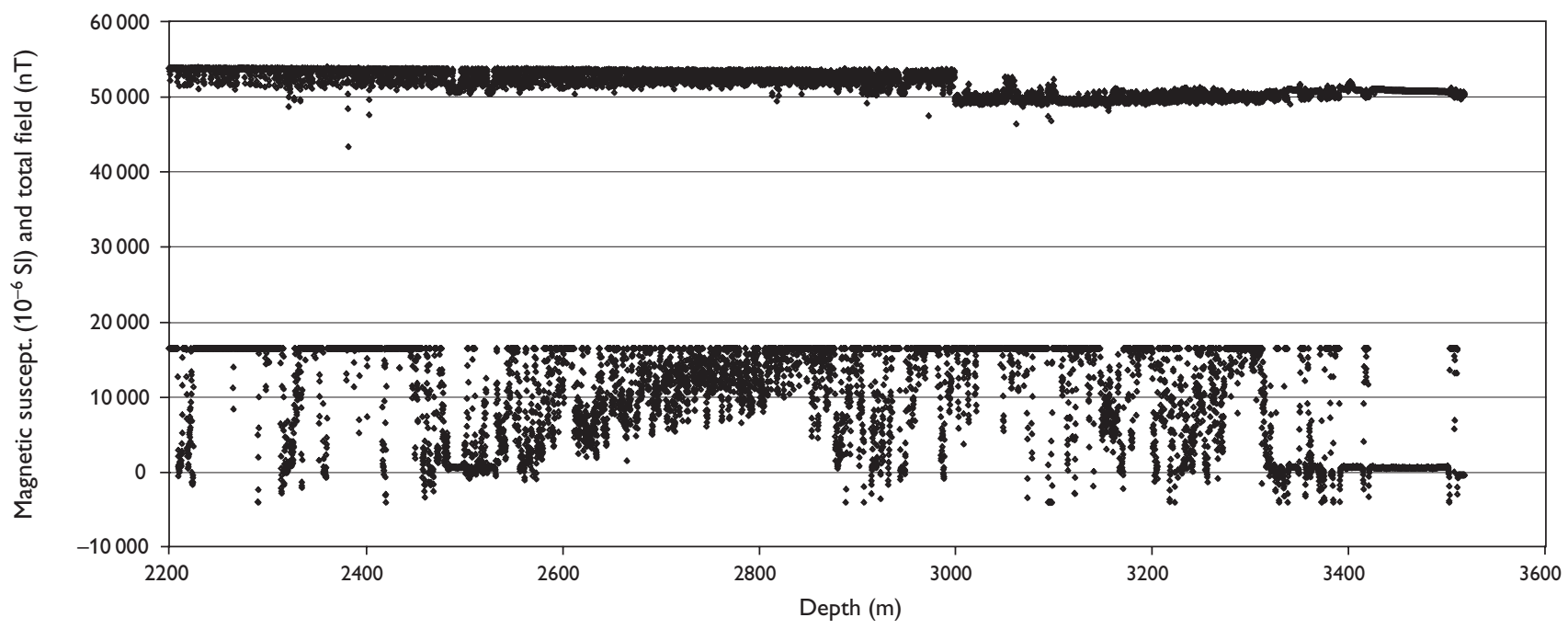

Fig. 2. Magnetic susceptibility $\left(\times 10^{-6} \mathrm{SI}\right)$ and the magnetic induction total field $(\mathrm{nT})$ logged in the Lopra-1/1A well between depths of 2200 and $3520 \mathrm{~m}$.

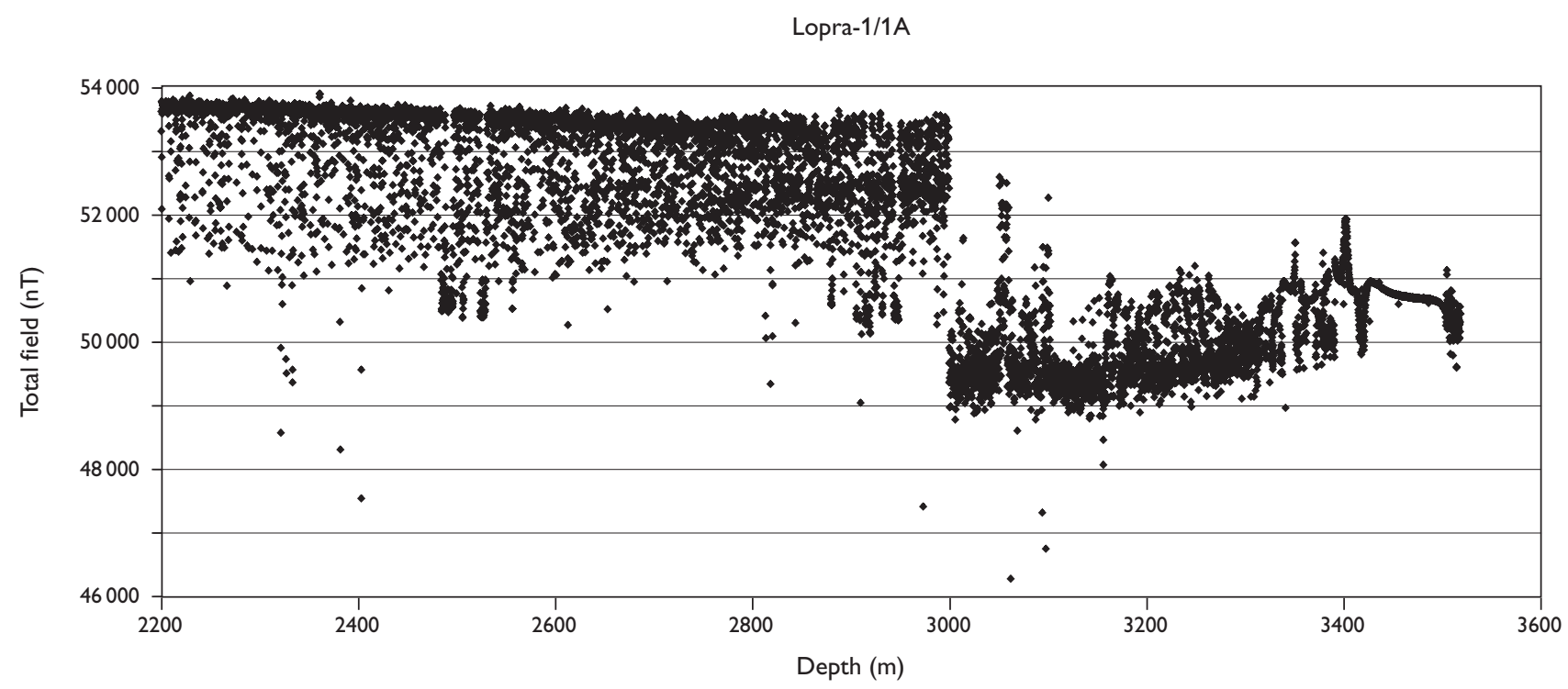

Fig. 3. Total magnetic field (magnetic induction, nT) in the Lopra-1/1A well. A jump in the general level of about $4000 \mathrm{nT}$ is seen at $3000 \mathrm{~m}$.

susceptibility was mostly outside the working range of the susceptometer. Because of this, the polarity of the remanent magnetisation and hence the interplay between the susceptibility and the induced magnetisation could not be deduced from these results and a reversal chronology could not be obtained from the in situ logged data.

Information about the remanent polarity of the rocks drilled by the Lopra-1/1A and Vestmanna-1 wells (Fig. 1) has, however, been obtained from drilled cores. These cores were investigated by traditional palaeomagnetic laboratory techniques and the results have been reported and pre- sented elsewhere (Schönharting \& Abrahamsen 1984; Abrahamsen et al 1984; Waagstein 1988; Abrahamsen 2006, this volume). Abrahamsen (2006, this volume) correlated the lowermost (unexposed) part of the $c .4 \frac{1}{2} \mathrm{~km}$ thick lower basalt formation with Chron 26r (Selandian) and the upper (exposed) part of the lower basalt formation with Chrons C26n, C25r and C25n (Selandian and Thanetian). The more than $2.3 \mathrm{~km}$ thick middle and upper basalt formations are correlated with Chron C24n.3r (Ypresian). 


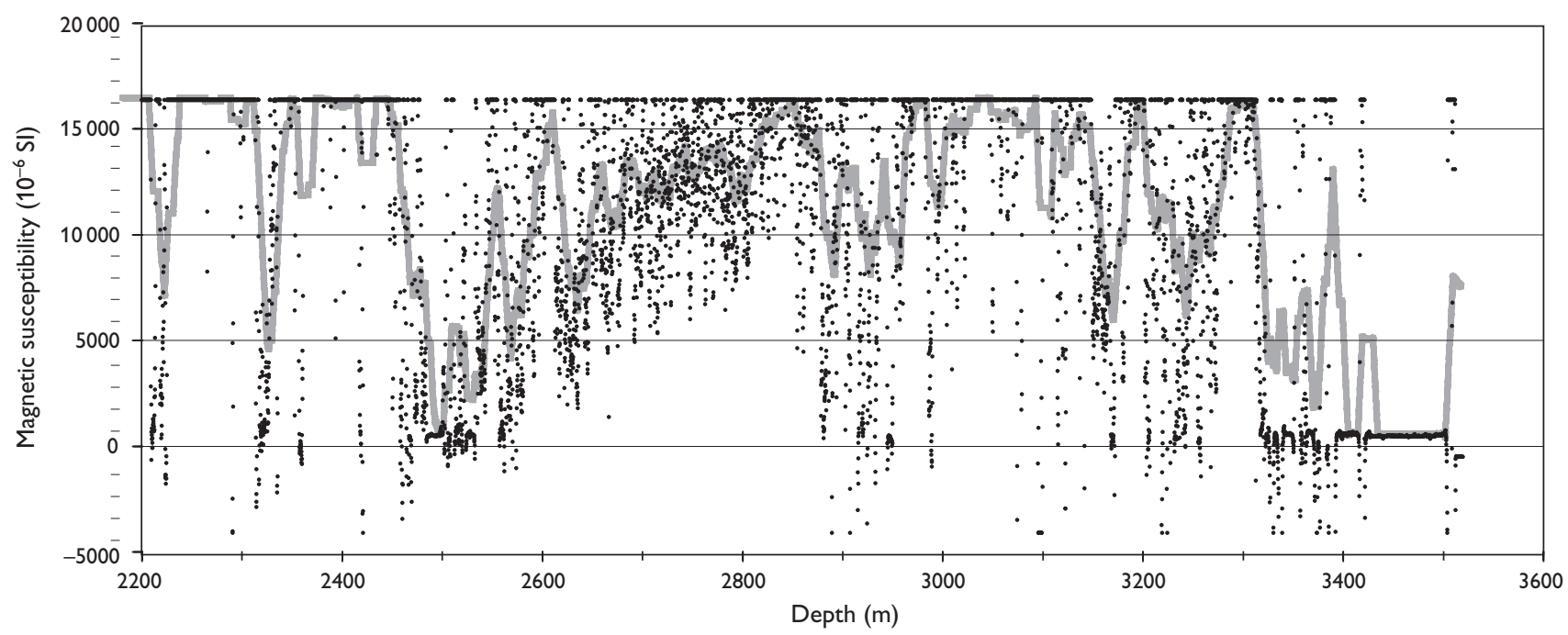

Fig. 4. Magnetic susceptibility log from the Lopra-1/1A well. The solid pale curve is a 100 point moving average (likely to be biased due to saturation of the instrument).

Lopra-1/1A

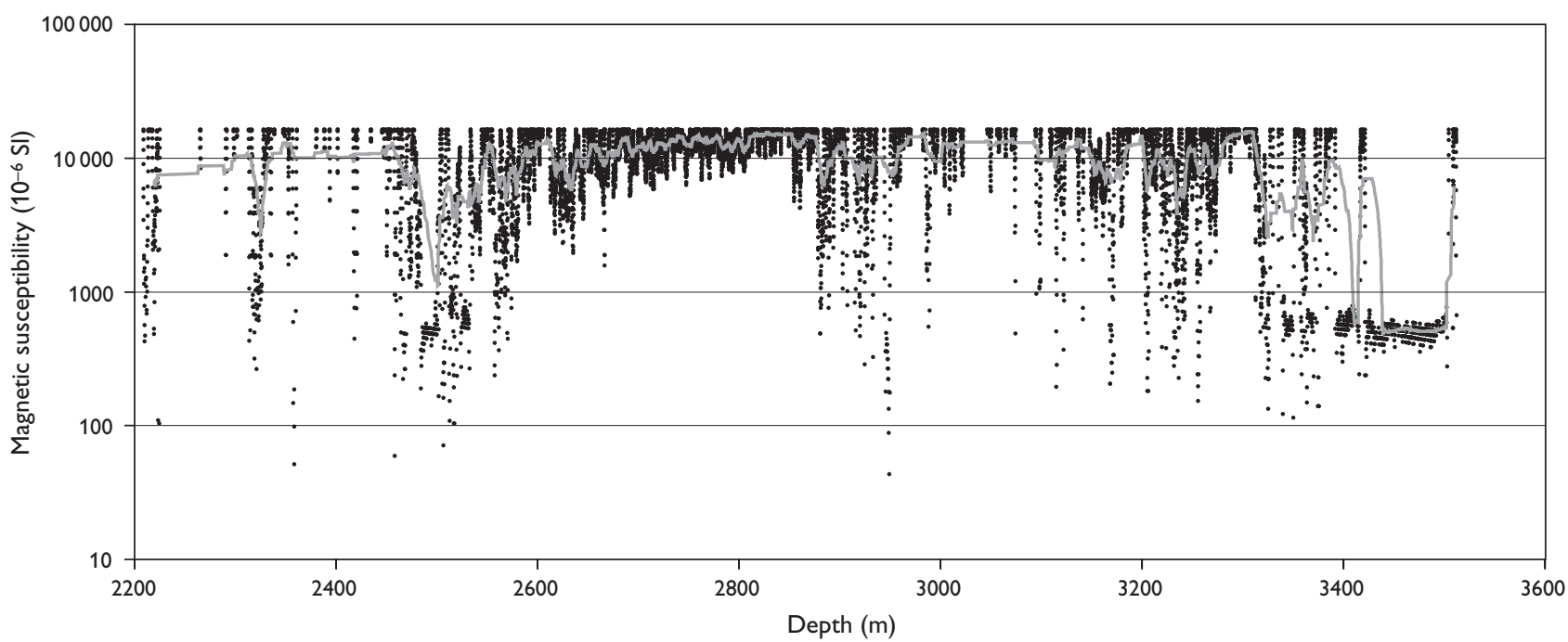

Fig. 5. Magnetic susceptibility from the Lopra-1/1A well (logarithmic scale). The solid pale curve is a 100 point moving average (likely to be strongly biased due to saturation of the instrument).

\section{Susceptibility of cores from the Lopra-1/1 A borehole}

The magnetic susceptibility of 1 conventional and 24 rotary sidewall cores drilled at regular intervals within the deepened part of the Lopra-1/1A well between 2275 and $3514.5 \mathrm{~m}$ has been measured in the laboratory. The cores include 14 basalts, 8 lapilli-tuffs and 2 tuffs (Table 1). A single plug from each sidewall core and 22 plugs from the $1.5 \mathrm{~m}$ long conventional core were measured.
The basalts fall into high- and low-susceptibility groups with no overlap. The high-susceptibility basalts are represented by seven cores with susceptibilities between 4 and $88 \times 10^{-3}$ SI. They consist of basalt with $<1 \%$ vesicles from thick massive units. The texture of the groundmass varies from intergranular with a few per cent matrix (mesostasis) to hyaline with almost $50 \%$ matrix. The matrix consists of cryptocrystalline quench crystals and secondary minerals replacing glass or filling interstitial voids. The groundmass of the intergranular basalts has an estimated 


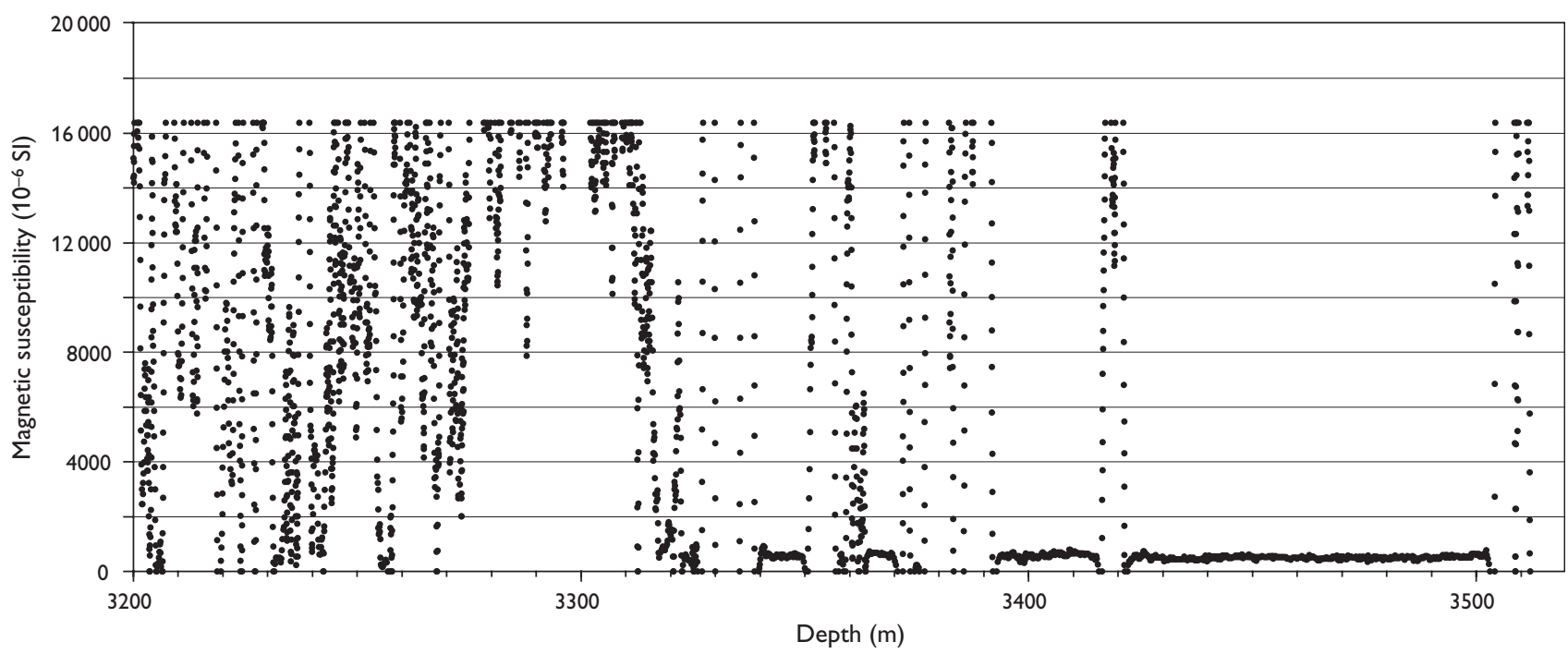

Fig. 6. Magnetic susceptibility details between 3200 and $3510 \mathrm{~m}$ of the Lopra-1/1A well.

Vestmanna-1

Rock magnetic properties

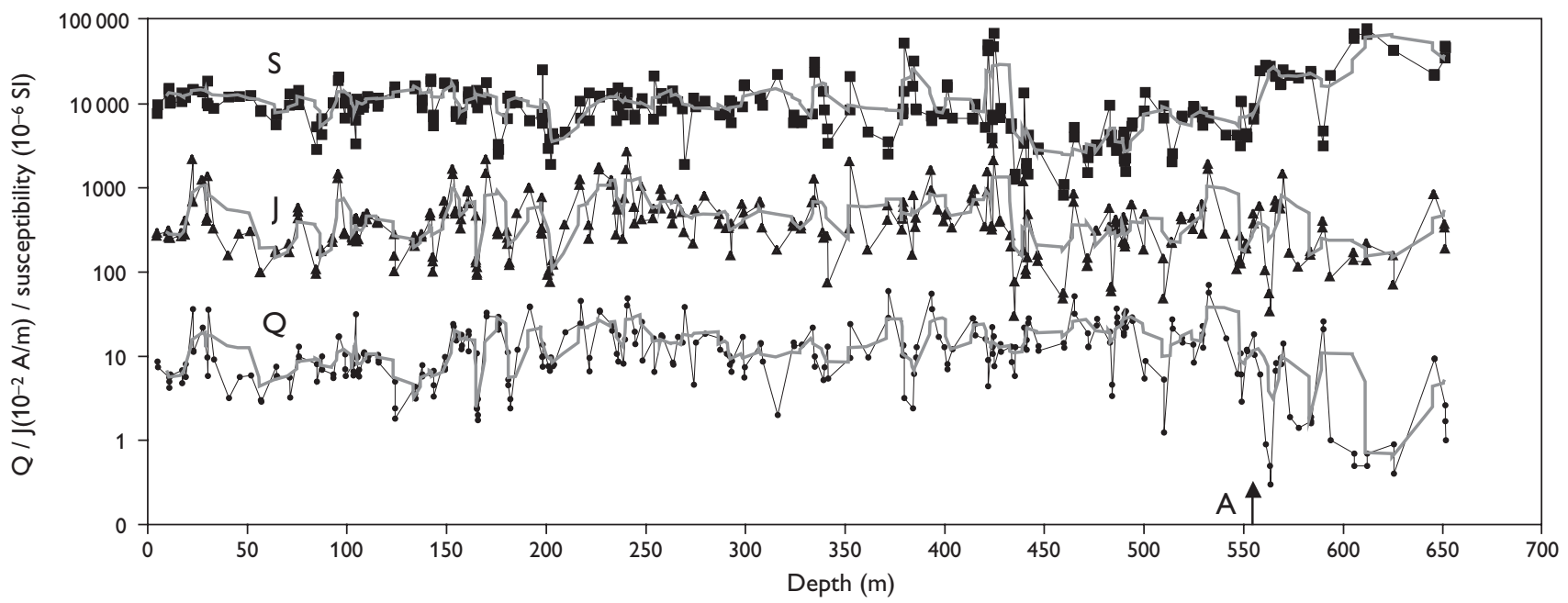

Fig. 7. Rock magnetic properties (susceptibility, NRM and Q-ratio) of the Vestmanna-1 well (modified from Abrahamsen et al. 1984). Pale curves are 5 point moving averages (logarithmic scale). The A horizon, between the lower and upper basalt formations, is marked by an arrow and the letter $\mathrm{A}$ at $557 \mathrm{~m}$.

content of 3-10 vol.\% titanomagnetite with a maximum size between $<0.03$ and $0.2 \mathrm{~mm}$. The titanomagnetite in the less crystalline basalts is too fine-grained to be estimated or cannot be seen, although the presence of an opaque or dark turbid matrix suggests that it is likely to be present.

Susceptibilities from seven cores from the low-susceptibility basalts vary from 0.6 to $1.4 \times 10^{-3} \mathrm{SI}$. The lowsusceptibility basalts are intergranular, intersertal or hypocrystalline and contain no or very little $(<1 \%)$ visible mag- netite. They are generally more altered than the high-susceptibility basalts and lose on average about $3.7 \mathrm{wt} \%$ volatiles on ignition compared to $1.8 \mathrm{wt} \%$ for the latter group (Table 1). The volatiles are dominantly crystal-bound water in secondary minerals including clay, zeolites, pumpellyite and phrenite. Three of the basalts are highly vesicular with $20-25 \%$ vesicles filled with secondary minerals.

The susceptibility of the ten volcaniclastites of lapillituff or tuff varies from 0.4 to $3.8 \times 10^{-3} \mathrm{SI}$ with an average of $1.1 \times 10^{-3}$ SI. The susceptibilities of the four deepest 


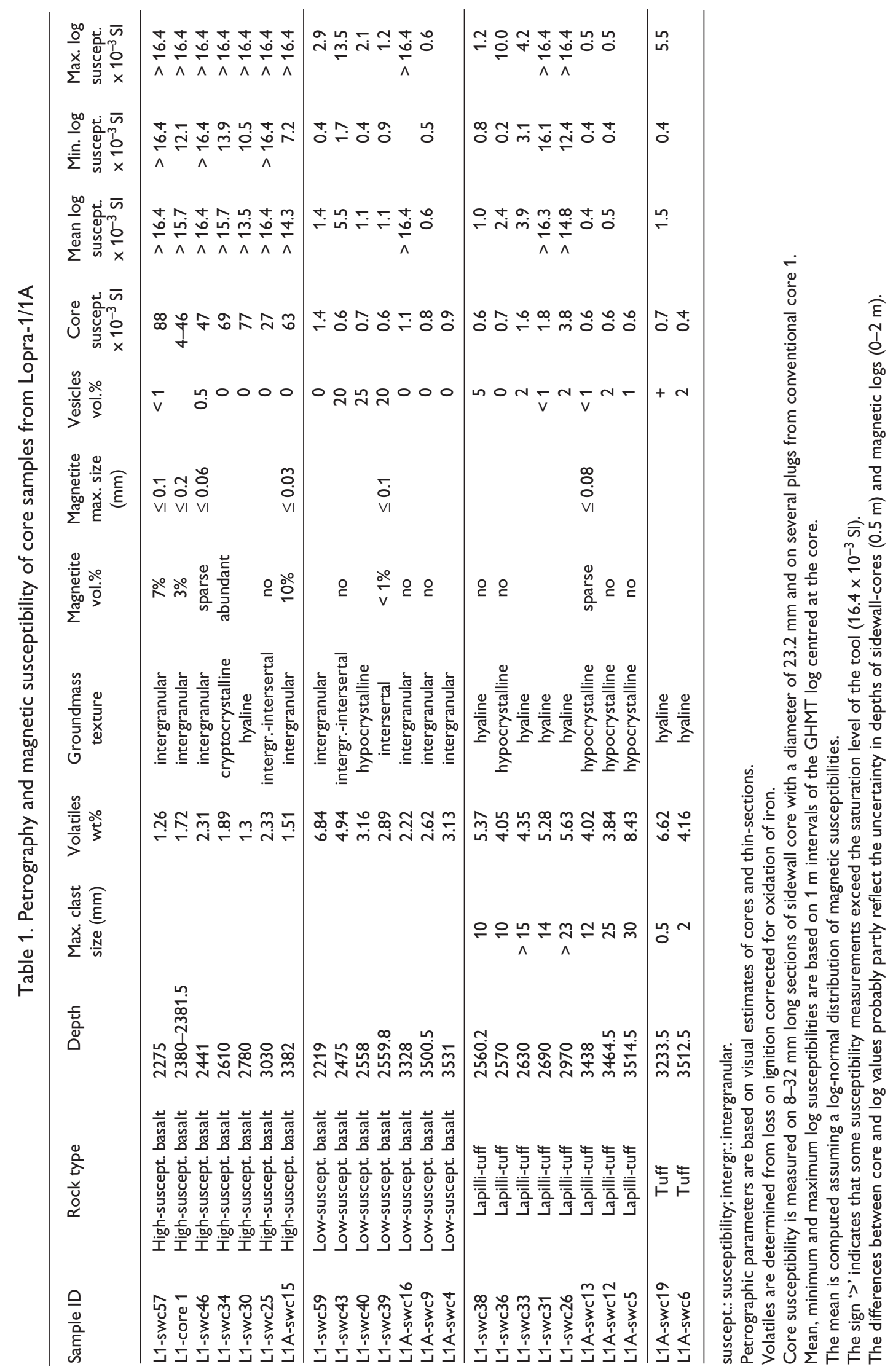


volcaniclastites from between 3438 and $3514.50 \mathrm{~m}$ average only $0.6 \times 10^{-3} \mathrm{SI}$.

The study of cores from the Lopra-1/1A well thus reveals a bimodal distribution of magnetic susceptibility. High-susceptibility rocks range between 4 and $88 \times 10^{-3} \mathrm{SI}$ with the great majority falling above $15 \times 10^{-3} \mathrm{SI}$. These rocks are all relatively fresh basalts from thick massive units cooled slowly enough to crystallise titanomagnetite (visible or not). The five cores from the original Lopra- 1 well all consist of intergranular basalts from the massive centre of thick flows (Hald \& Waagstein 1984) with susceptibilities between 16 and $39 \times 10^{-3}$ SI (Schönharting \& Abrahamsen 1984) and thus belong to the group of highsusceptibility basalts.

Low susceptibilities from the Lopra-1/1A borehole, ranging from 0.4 to $4 \times 10^{-3} \mathrm{SI}$, are characteristic of both altered basalts poor in magnetite $\left(0.6-1.4 \times 10^{-3} \mathrm{SI}\right)$, lapillituffs $\left(0.6-3.8 \times 10^{-3} \mathrm{SI}\right)$ and tuffs $\left(0.4-0.7 \times 10^{-3} \mathrm{SI}\right)$. This means that single measurements of susceptibility are oflittle use in discriminating between these three types of rock.

\section{The Lopra-1/1 A magnetic log}

Because the recorder was run in its low-resolution mode, the susceptibilities of most of the rocks through which it passed were mostly outside its recording range. Nevertheless, some general lithological features may be deduced (Schlumberger Ltd., personal communication 1997). The upper recording limit of $16.4 \times 10^{-3}$ SI is close to the typical lower limit of relatively fresh, massive basalt. This means that major intervals of saturation are a good indicator of massive basalt units.

This makes it possible to divide the logged interval into two parts, below and above 3315 m (cf. Figs 4-6).

\section{Below 3315 m}

The lower part displays a highly bimodal pattern with two distinct susceptibility levels. About $85 \%$ of the logged section below $3315 \mathrm{~m}$ shows average susceptibilities around $0.7 \times 10^{-3}$ SI that we interpret as hyaloclastites. Basalt layers with a thickness from 2 to $6 \mathrm{~m}$ are clearly identifiable within the hyaloclastites showing sharp contacts and much higher susceptibility values (to above the recorded saturation limit of $\left.16.4 \times 10^{-3} \mathrm{SI}\right)$. Low-susceptibility basalt has been cored nearby (Table 1) so the high-susceptibility intervals give only a minimum estimate of the thickness of basalt present.

For comparison, a $1 \frac{1 / 2}{2}$ solid basalt core from 2381 $\mathrm{m}$ and 24 sidewall basalt cores (Abrahamsen 2006, this volume) had a mean susceptibility of $22.1 \times 10^{-3} \mathrm{SI} \pm 3.5$ (one standard deviation $(\sigma)=23.6$, number of samples $(\mathrm{N})=46$ ), whereas samples of hyaloclastite (tuffs and lapilli-tuff) had a mean value of $0.85 \times 10^{-3} \mathrm{SI}(\sigma=0.39, \mathrm{~N}=$ 17). These results thus compare quite well with the average of the susceptibility log data.

The total magnetic field (magnetic induction) shows a jump of about $4000 \mathrm{nT}$ between the two partly overlapping $\log$ runs (log sections spliced at $3000 \mathrm{~m}$; Figs 2-3), which must be an artifact. The magnetometer record of the total field below $3315 \mathrm{~m}$ (Fig. 3) shows the typical effect of a highly magnetised layer within a weakly magnetised formation. The induction recorded through the volcaniclastics below and above the basalt is strongly affected by the distance to the basalt. Several occurrences of such basaltic layers give rise to mixed effects through the volcaniclastics.

\section{Above $3315 \mathrm{~m}$}

The total-field magnetometer was saturated above 53500 $\mathrm{nT}$ during most of the first logged section between 3101 and $2168 \mathrm{~m}$ (Figs 2-3). This value is stronger than the local Earth's magnetic field of around $50000 \mathrm{nT}$ and could indicate a large local magnetic source of unknown origin, but is more likely a tool or calibration error. In contrast, despite the very variable character of the lower section, this is not the case for the uppermost part of the lower section (below 3315 m, Fig. 3). In both cases the magnetometer was preset for maximum sensitivity of values centred at the expected value of the local Earth's magnetic field strength of $50000 \mathrm{nT}$.

Above $3315 \mathrm{~m}, c .70 \%$ of the susceptibility data (Figs $2,4-6)$ are greater than $16.4 \times 10^{-3}$ SI (the saturation level of the instrument). Thick intervals above saturation level are dominant above $2550 \mathrm{~m}$ and reflect subaerial basalt flows. Between about 2550 and $3315 \mathrm{~m}$, the susceptibility log is characterised by large short-scale variations. Strong variability is especially observed in the interval from 2613 to $2816 \mathrm{~m}$ (Fig. 4). The high-frequency pattern originates from a succession of hyaloclastites and minor basalt beds. The hyaloclastites consist of lapilli-tuffs, tuff-breccias, breccias and subordinate tuffs. The variability may be explained by the presence of large clasts of basalts showing high susceptibilities set in a low-susceptibility tuffaceous matrix. Only a few longer intervals of low susceptibility $\left(<1 \times 10^{-3} \mathrm{SI}\right)$ can be recognised above 3315 $\mathrm{m}$, the thickest ones being between 2945 and $2950 \mathrm{~m}$, between 2523 and 2533 and between 2484 and $2500 \mathrm{~m}$. 
The other rock magnetic properties of the Lopra-1/1A well, including the magnetic polarity and correlation with the GPTS, have been summarised and discussed in details elsewhere (Abrahamsen 2006, this volume).

\section{Rock magnetic properties in the Vestmanna-1 well}

The 660 m deep Vestmanna-1 well on Streymoy (Fig. 1) was drilled in 1980 through the lower part of the Faroes middle basalt formation and into the top of the lower basalt formation using wireline coring technique.

No magnetic in-hole logging was made during or after the drilling. However, detailed magnetic laboratory investigations of sub-sampled plugs of the fully recovered core have been published (Abrahamsen et al. 1984). An illustration of most of the rock magnetic information obtained (susceptibility S, NRM intensity J, and Q-ratio) is shown in Fig. 7 on logarithmic scales (modified from the original data presented by Abrahamsen et al. 1984). The thick pale curves are five point moving averages.

The well reached $101 \mathrm{~m}$ into the upper part of the $c$. $41 / 2 \mathrm{~km}$ thick lower basalt formation (Waagstein 1988) whose top is indicated in Fig. 7, where a $0.7 \mathrm{~m}$ thick basaltic conglomerate of local origin separates the lower and the middle basalt formations (Waagstein \& Hald 1984). Rocks penetrated by the overlying part of the well (0-557 $\mathrm{m}$ in Fig. 7) all belong to the middle basalt formation. The conglomerate is stratigraphically equivalent to a $c$. $10 \mathrm{~m}$ thick sediment sequence in the south and southwestern parts of the Faroe Islands that includes thin beds of coal indicating a long quiescence in the magmatic activity between eruption of the lower and middle basalt formations.

All three rock magnetic parameters vary more than one order of magnitude, which is not uncommon for the magnetic properties of volcanic rocks. The mean values for each of them $(\mathrm{N}=303$ samples $)$ are $\mathrm{Q}_{\mathrm{ave}}=13.3 \pm 0.6(\sigma=$ $11), S_{\text {ave }}=11.8 \pm 0.6 \times 10^{-3} \mathrm{SI}(\sigma=11)$ and $\mathrm{J}_{\text {ave }}=4.64 \pm$ $0.25 \mathrm{~A} / \mathrm{m}(\sigma=4.4)$. The only readily apparent systematic trend appears to be a decrease in the susceptibility from high values at $610 \mathrm{~m}$ to low values at $440 \mathrm{~m}$. At shallower depths, the susceptibility fluctuates around $10^{-2}$ SI. The trend is mirrored in the Q-ratio below $470 \mathrm{~m}$, but with a slight decrease in Q above this level, whereas no systematic trends appear visible in the NRM intensity.

The magnetic polarity of the Vestmanna-1 well was determined in detail by palaeomagnetic investigations of 303 up-oriented plugs from the fully cored borehole, that indicate a short normal polarity interval between 660 and
$640 \mathrm{~m}$ only, all the younger samples $(\mathrm{N}=275)$ being reversed (Abrahamsen et al. 1984).

\section{Conclusions}

Due to instrument problems, the valuable information from the magnetic logs of the Lopra-1/1A well is limited. Based upon the logged susceptibility, the variation below $3315 \mathrm{~m}$ is clearly diagnostic between volcaniclastics (with low and fairly constant susceptibility) and basalt flows of between 5 and $10 \mathrm{~m}$ in thickness (with high susceptibility). Between 3315 and $3515 \mathrm{~m}$ the volcaniclastics comprise some $60-70 \%$ of the sequence, the maximum continuous layer being $80 \mathrm{~m}$ thick.

A $1 \frac{1 / 2}{m}$ long core of solid basalt from $2381 \mathrm{~m}$ and sidewall cores of basalt from the Lopra-1/1A well have a mean susceptibility of $22.1 \times 10^{-3} \mathrm{SI} \pm 3.5(\sigma=23.6, \mathrm{~N}=$ 46), while samples of volcaniclastics (lapilli-tuff and tuff) have a mean value of $0.85 \times 10^{-3} \mathrm{SI}(\sigma=0.39, \mathrm{~N}=17)$.

The mean values of rock magnetic parameters for 303 basalt plugs from the Vestmanna-1 well are: $\mathrm{Q}_{\text {ave }}=13.3 \pm$ $0.6(\sigma=11), S_{\text {ave }}=11.8 \pm 0.6 \times 10^{-3} \mathrm{SI}(\sigma=11)$ and $\mathrm{J}_{\text {ave }}=$ $4.64 \pm 0.25 \mathrm{~A} / \mathrm{m}(\sigma=4.4)$. The reversely polarised, lowermost (hidden) part of the $c .41 \frac{1}{2} \mathrm{~km}$ thick lower basalt formation correlates with Chron C26r. The upper (exposed) part of the lower basalt formation correlates with Chrons C26n, C25r and C25n and the more than 2.3 $\mathrm{km}$ thick middle and upper basalt formations correlate with Chron C24n.3r.

\section{References}

Abrahamsen, N. 2006: Palaeomagnetic results from the Lopra1/1A re-entry well, Faroe Islands. Geological Survey of Denmark and Greenland Bulletin 9, 51-65 (this volume).

Abrahamsen, N., Schönharting, G. \& Heinesen, M. 1984: Palaeomagnetism of the Vestmanna core and magnetic age and evolution of the Faeroe Islands. In: Berthelsen, O., Noe-Nygaard, A. \& Rasmussen, J. (eds): The Deep Drilling Project 1980-81 in the Faeroe Islands. Annales Societatis Scientiarum Faeroensis, Supplementum IX, 93-108. Tórshavn: Føroya Fróðskaparfelag.

Barthés,V., Pozzi, J.P., Vibert-Charbonnel, P., Thibal, J. \& Mélières, M.A. 1999: High-resolution chronostratigraphy from downhole susceptibility logging tuned palaeoclimatical orbital frequencies. Earth and Planetary Science Letters 165, 97-116.

Bouisset, P.M. \& Augustin, A.M. 1993: Borehole magnetostratigraphy, absolute age dating and correlation of sedimentary rocks, with examples from the Paris Basin, France. American Association of Petroleum Geologists Bulletin 77, 569-587. 
Broding, R.A., Zimmermann, C.W., Sommers, E.V., Wilhelm, E.S. \& Stripling, A.A. 1952: Magnetic well logging. Geophysics 17, $1-26$.

Cox, A., Doell, R. \& Dalrymple, G.B. 1963: Geomagnetic polarity epochs and Pleistocene geochronometry. Nature 198, 10491051.

Hald, N. \& Waagstein, R. 1984: Lithology and chemistry of a 2$\mathrm{km}$ sequence of lower Tertiary tholeiitic lavas drilled on Suðuroy, Faeroe Islands (Lopra-1). In: Berthelsen, O., Noe-Nygaard, A. \& Rasmussen, J. (eds): The Deep Drilling Project 1980-81 in the Faeroe Islands. Annales Societatis Scientiarum Faeroensis, Supplementum IX, 15-38. Tórshavn: Føroya Fróðskaparfelag.

Heirtzler, J.R., Dickson, G.O., Herron, E.M., Pitman III, W.C. \& Le Pichon, X. 1968: Marine magnetic anomalies, geomagnetic field reversals and motions of the ocean floor and continents. Journal of Geophysical Research 73, 2119-2136.

Ito, H. \& Nogi, Y. 1995: Magnetic structures of seamounts in the western Pacific Ocean deduced from Leg 144 downhole magnetometer logs. Proceedings of the Ocean Drilling Program, Scientific Results 144, 631-638.

Levanto, A.E. 1958: A three-component magnetometer for small drill-holes and its use in ore prospecting. Geophysical Prospecting 7, 183-195.

Parasnis, D.S. 1979: Principles of applied geophysics, 275 pp. London: Chapman \& Hall.

Pozzi, J.P., Martin, J.P., Pocachard, J., Feinberg, H. \& Galdeano, A. 1988: In situ magnetostratigraphy: interpretation of magnetic logging in sediments. Earth and Planetary Science Letters 88, 357-373.
Pozzi, J.P., Barthés, V., Thibal, J., Pocachard, J., Lim, M., Thomas, T. \& Pagès, G. 1993: Downhole magnetostratigraphy in sediments: comparison with the paleomagnetism of a core. Journal of Geophysical Research 98, 7939-7958.

Schönharting, G. \& Abrahamsen, N. 1984: Magnetic investigations on cores from the Lopra-1 drillhole, Faeroe Islands. In: Berthelsen, O., Noe-Nygaard, A. \& Rasmussen, J. (eds): The Deep Drilling Project 1980-81 in the Faeroe Islands. Annales Societatis Scientiarum Faeroensis, Supplementum IX, 109-114. Tórshavn: Føroya Fróðskaparfelag.

Vine, F.J. \& Matthews, D.H. 1963: Magnetic anomalies over ocean ridges. Nature 199, 947 only.

Waagstein, R. 1988: Structure, composition and age of the Faeroe basalt plateau. In: Morton, A.C. \& Parson, L.M. (eds): Early Tertiary volcanism and the opening of the NE Atlantic. Geological Society Special Publication (London) 39, 225-238.

Waagstein, R. \& Hald, N. 1984: Structure and petrography of a $660 \mathrm{~m}$ lava sequence from the Vestmanna-1 drill hole, lower and middle basalt series, Faeroe Islands. In: Berthelsen, O., NoeNygaard, A. \& Rasmussen, J. (eds): The Deep Drilling Project 1980-81 in the Faeroe Islands. Annales Societatis Scientiarum Faeroensis, Supplementum IX, 39-70. Tórshavn: Føroya Fróðskaparfelag.

Waagstein, R., Guise, P. \& Rex, D. 2001: K/Ar and ${ }^{39} \mathrm{Ar} /{ }^{40} \mathrm{Ar}$ wholerock dating of zeolite-facies metamorphosed flood basalts: the upper Paleocene basalts of the Faroe Islands, NE Atlantic. In: Jolley, D.W. \& Bell, B.R. (eds): The North Atlantic igneous province: stratigraphy, tectonic, volcanic and magmatic processes. Geological Society Special Publication (London) 197, 219-252. 